\title{
Assessment of Progress Made in Health Infrastructure and Manpower through NRHM and Their Impact in Reducing IMR in India
}

\author{
M. R. Singariya* \\ Lecturer in Economics, Govt. College Jaitaran (Raj), India \\ *Corresponding author: mr.singariya@gmail.com
}

Received September 13, 2013; Revised November 14, 2013; Accepted December 11, 2013

\begin{abstract}
One of the prime objectives of the National Rural Health Mission (NRHM) is to reduce the Infant Mortality Rate (IMR) in India. Different strategies adopted for child health under NRHM are directed to reduce IMR. Using review of available data sources and published literature, the paper aims to examine the impact of NRHM initiatives like health infrastructure and manpower in reducing IMR. The mission had set specific targets; these include a reduction in the infant mortality rate to 30 per 1000 live births. At the national level, there was a decline in the infant mortality rate from 58 per thousand live births in 2005 to 44 in 2011 (all India) after implementation of NRHM. The IMR in focus states like Bihar fell from 61 to 44, in Madhya Pradesh from 76 to 59, in Rajasthan from 68 to 52 and in Assam from 68 to 55. However, 14 states/UTs have already achieved MDG 4 of IMR. These figures are, however, still dismal even when compared to the target IMR rate of 30 under NRHM. Thus the NRHM has had an impact but a rather limited one.
\end{abstract}

Keywords: IMR, NRHM, health infrastructure, manpower, India

Cite This Article: M. R. Singariya, "Assessment of Progress Made in Health Infrastructure and Manpower through NRHM and Their Impact in Reducing IMR in India.” Journal of Finance and Economics 1, no. 4 (2013): 118-127. doi: 10.12691/jfe-1-4-9.

\section{Introduction}

India's National Rural Health Mission (NRHM) was launched in 2005 and in the last seven years of the implementation of the mission the infant mortality rate declined from 58 in 2005 to 44 in 2011. The annual rate of decline of IMR accelerated by about 37 percent in between 2005-11 (after the inception of NRHM in 2005) as compared to 2000-2005. This is expected to show even better performance after latest survey results are known. While there has been a significant improvement in the rate of reduction of IMR, there is still a need to improve further ${ }^{1}$.

Seven years ago, the National Rural Health Mission (NRHM) was launched with the aim to provide accessible, affordable and accountable quality health services to the poorest households in the remotest rural regions. With barely three years of the mission remaining, it may be worthwhile to take a look at the progress that has so far been made in achieving the objectives that had been set out. A preliminary assessment of the programme, based on health indicators, shows that the government has had very limited success in achieving its objective to establish a fully functional, community-owned, decentralized health delivery system.

The mission was launched to correct the skewed access to health care facilities between the urban and rural areas.
While there were a plethora of schemes that catered to the healthcare needs of urban areas, there was little that had been done to set up a functioning rural health care system. One of the main reasons for inequalities in access to health care facilities between the rural and urban areas was the lack of good medical infrastructure in rural areas of most states, particularly Arunachal Pradesh, Assam, Bihar, Chhattisgarh, Himachal Pradesh, Jharkhand, Jammu and Kashmir, Manipur, Mizoram, Meghalaya, Madhya Pradesh, Nagaland, Orissa, Rajasthan, Sikkim, Tripura, Uttarakhand and Uttar Pradesh. Because the NRHM was specifically aimed at removing infrastructural (both physical and human) bottlenecks that resulted in unequal access, states with unsatisfactory health indicators and/or with weak infrastructure were classified as high focus states to ensure that efforts were concentrated where it was most needed.

In India, during 1968-70, the level of IMR was stable at 130 deaths per 1000 live-births. Following the Alma Ata Declaration of 1978, the Government of India envisaged a national goal for the attainment of an IMR of 60 by the year 2000. Since then, substantial resources have been put into the child survival programmes over the past 25 years. The Sixth and Seventh Five-Year Plans had aimed at nationwide programmes to realize this goal. The twentypoint programme included, as a key component, rapid improvement in the conditions of women and children. In 1979, the Expanded Programme of Immunization (EPI) was established to provide the tetanus toxoid (TT) vaccine 
to pregnant women, and BCG, DPT, polio and measles vaccine to children. The Universal Immunization Programme (UIP) and oral rehydration therapy (ORT) were both launched in 1985 and the Safe Motherhood Programme initiated during the Eighth Plan was among the prominent components of the Family Welfare Programme. In the early 1990s, these programmes were integrated and further strengthened to shape the Child Survival and Safe Motherhood (CSSM) Programme. In 1994, the CSSM Programme was further expanded to the Reproductive and Child Health ( $\mathrm{RCH})$ services. These programmes had the desired effect of reducing child mortality and improving child health as evidenced from the child mortality statistics of 1978-2002. The National Population Policy (2000) and National Health Policy (2002) addressed the issues of child survival and maternal health, and increased the outreach and coverage of the comprehensive package of $\mathrm{RCH}$ services through the government as well as the voluntary non-government sector together [1].

The National Rural Health Mission (2005-12) seeks to provide effective healthcare to rural population throughout the country with special focus on 18 states, which have weak public health indicators and/or weak infrastructure. These 18 States are Arunachal Pradesh, Assam, Bihar, Chhattisgarh, Himachal Pradesh, Jharkhand, Jammu \& Kashmir, Manipur, Mizoram, Meghalaya, Madhya Pradesh, Nagaland, Orissa, Rajasthan, Sikkim, Tripura, Uttaranchal and Uttar Pradesh. The Mission is an articulation of the commitment of the Government to raise public spending on Health from $0.9 \%$ of GDP in $2-3 \%$ of GDP [2].

Mortality is very responsive to social, economic and psychological factors. Historically, mortality has often used as a barometer of welfare. Statistical studies in the nineteenth and twentieth centuries showed concern for socioeconomic differences in infant and crude mortality. Level of death rate; more importantly, infant mortality reflects a society's status of well being. Such aspects can be taken as indicators of quality of life. The infant mortality rate (IMR) is defined as the risk for a live born child to die before its first birthday is known to be one of the most sensitive and commonly used indicators of the social and economic development. Children are important assets of a nation; therefore reduction in infant mortality is likely the most important objective of the any development plan. Infant mortality rate reflects a country's level of socioeconomic development and is used for monitoring and evaluating population, health programs and policies [6]. It is an outcome rather than a cause and hence directly measures the results of the distribution and use of resources. Figure 1 shows the level of infant mortality rate in selected sixteen countries in 2010. Countries like Japan, France, Norway, Germany, Australia, United Kingdom, Italy, and the United States have below 10 per thousand live births infant mortality, while Russia, China and Sri Lanka are ranging between 10 to20 IMRs. Most of the African countries are struggling with the infant mortality level of near fifty per thousand live births in a year in 2010. India and South Africa lie in the range of 40-50 infant deaths per thousand live births, while some other South Asian countries like Bangladesh and Pakistan have above fifty IMRs. It suggests that level of infant mortality in India is still too high and we are very far from our neighboring and developing countries like China and Sri Lanka. According to United Nations estimates; India accounts a quarter of total infant deaths in the world. Thus any study of Indian mortality has global significance.

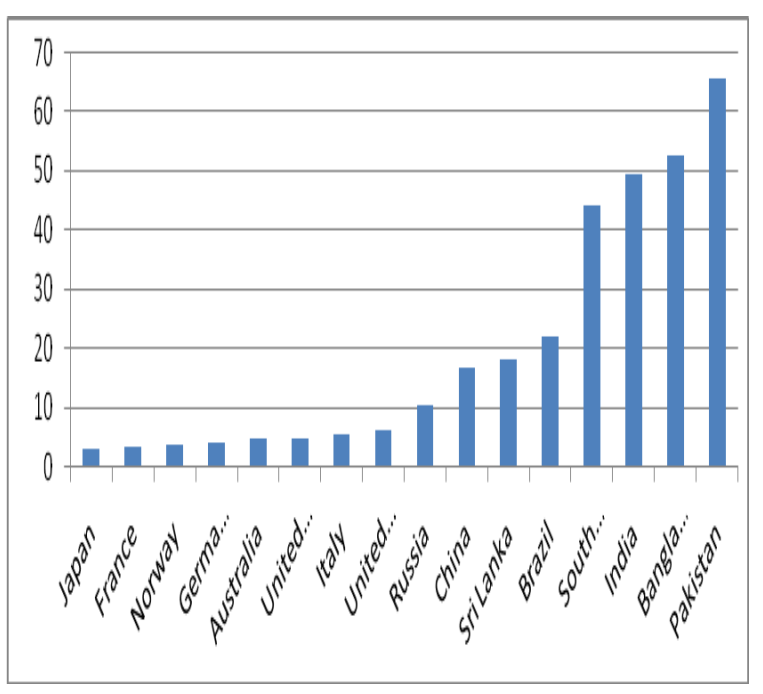

Figure 1. Infant Mortality Rate for Selected Countries, 2010, ( Source: U.S. Census Bureau, International Database)

India has experienced an impressive decline in infant mortality since 1970s. From 130-140 deaths per one thousand live births in the early 1970s, mortality levels have declined to as low as 44 deaths per one thousand live births in 2011 (Economic Survey, 2012-13). India is a very diverse country by its demography. Due to wide interstate variations, it is always meaningless to talk about an average infant mortality rate for India. There are very basic variations in the levels and declining rate of infant mortality rate in major states of India [3,4].

The infant mortality rate for the most recent time period (2011) is 44 deaths per 1000 live births and which was 43 for male and 46 for female infants in India. This means that still 1 in 23 children die in India before reaching the first birthday and in case of the female infant's problem is deeper, for every one in 22 die before her first birthday. The research questions related to public health and especially a child or infant health is obvious. If infant mortality reflects a society's status of wellbeing and societal health can be measured by it, what are the various factors that increase or decrease it? Can the marginal effects of these factors improve the existing level? If so, which of these factors produces the largest health benefits to society? These questions are as important now as earlier. In this paper, a new attempt has been made to relate IMR with NRHM initiatives like health infrastructure and manpower and impact in reducing IMR in India in the light of above discussed research questions through econometric models.

\section{Review of Literature}

Historically high levels of infant mortality have been linked to infection and poor nutrition, which are still significant contributing factors in non-developed countries. High levels of infant mortality are also linked to preterm and low birth weight babies, and much of the reduction in infant mortality rates in the U.S. in the last half of the 
twentieth century has been linked to better medical techniques to increase these infant's chance of survival. Progress in this area seems to have stagnated in recent years. Other risk factors believed to be linked to infant mortality include poor health of the mother (diabetes and chronic hypertension) and the mother's us of alcohol, tobacco, and other drugs [5,6].

Given the micro-level evidence on the success of selected public health intervention programs, the limited role of economic growth in explaining health improvements, and the ongoing debate over aid effectiveness, it is important to understand the relationship between foreign aid and health outcomes. Despite the vast empirical literature considering the effect of foreign aid on growth, there is little systematic empirical evidence on how overall aid affects health, and none (to our knowledge) on how health aid affects health [7].

Previous researchers have come to mixed conclusions about the effect of government intervention in the health care industry. Himmelstein and Woolhandler (1986) [8] believe that a nationalized health care system can increase life expectancy while controlling health care costs. Shortell and Hughes (1988) [9] believe that increased competition in the health care industry would lead to a decreased quality of health care. Ohsfeldt (2003) [10] examined survival rates of cancer patients in developed countries and showed that the United States health care system did significantly out perform other countries for those who could obtain treatment. The theory of government enterprise [11] (Ahlbrandt 1973), and the theory of economic regulation [12] (Stigler 1971) both suggest that government interference in the health care industry increase cost and does not increase health care quality. Friedman [13] (2001) found that government interference in the health system decreased available health care resources while increasing costs. Santerre, Grubaugh, and Stollar [14] (1991) found no direct effect of government intervention on infant mortality or health care costs, but concluded that government intervention in the economy will negatively impact economic growth which will then negatively impact health care.

To reduce infant mortality significantly, it is required to focus on the mother's level of education, which is inversely related to her child's risk of dying. Significant differentials have been observed by different years in Gross Domestic Product (GDP), Per capita health expenditure, mean age at marriage of female, the literacy rate of female and a source of pure drinking water attainment at a mortality rate [15].

Caldwell (1979) examines education as a factor in mortality decline using the Nigerian data. His stress on the role of parental education, particularly mother, in reducing infant and child mortality. He argued that a well educated mother can change the range of feeding and child care practices without imposing significant extra cost on the household [16].

Kisor and Parsuraman (1998) using data from the 199293, National Family Health Survey, found that mother's income translates into greater control over the expanding of resources, increased exposure and access to relevant information about childbearing and childrearing practices. Their study showed that mothers who are employed have a 10 percent higher infant mortality rate and a 36 percent child mortality rate than mothers who are not employed.
Another issue of interest is whether urbanization plays an important role in influencing mortality levels. Greater urbanization should lead to lower mortality levels. Finally, the relationship between poverty and mortality is worth noticing. Does poverty have a strong effect on mortality rates after controlling for the other explanatory variables?

In India (1971 Census data) availability of family planning clinics and dispensaries significantly reduce woman's child mortality ratios, while hospital have a negative but insignificant effect on mortality. They found that doubling the number of villages with family planning programs reduce child mortality ratio by about $10 \%$ while doubling the number of villages with dispensaries would lower the ratios by 25\% [17].

Da Vanzo (1984) tests for a relationship between distance to facilities and infant mortality with data collected as part of Malaysian family Life Survey. She found no evidence that such relationship exists possibly because the mortality data dates as far back as to late 1940s while the facility data refers to the time of survey.

No clear picture of effect of access to services on health outcomes emerges from above mentioned studies. Some health services improve health outcomes in some settings [17]. In other settings access to health services appear to have no effect on health outcomes [18]. While it is unreasonable to expect perfect consistency across studies from a multitude of countries and time periods relating to disparate health services to various health outcomes, the review fails to build a compelling body of evidence regarding the importance of health outcomes.

\section{Objectives}

Using review of available data sources and published literature, this paper aims to examine the scenario of infant mortality over the last seven years and the impact of NRHM initiatives like health infrastructure and manpower over the same.

\section{Data \& Methods}

Data used in this paper are collected from various SRS Bulletins, Sample Registration System, office of the Registrar General, India and Rural Health Statistics in India, 2012, Ministry of Health and Family Welfare, Government of India, $30^{\text {th }}$ April, 2013. It has been trying to explain the status of health infrastructure and health works in 2005 and changes occurring in them in 2012 through charts and figures. Finally, the Step wise regression model has been used to explain whether strengthening of health infrastructural facilities and health worker have any impact on the declining infant mortality rate in India during 2005-12 [19,20].

\section{Results}

Residence wise trends of the Infant mortality Rate of India during 1980 -2011, has been shown in Figure 1. It depicts a declining trend during 1980 -2011. Rural IMRs have been declined 76 points from 124 in 1980 to 48 in 2011 while urban IMRs have been registered 36 points 
decline in the same period (Table 1). To find out the impact of NRHM on Infant mortality rate, it is necessary to calculate the level of IMR separately for pre and post NRHM implementation period. We have calculated annual rate of reduction in IMR during 1980-2011 (Table 2). It clearly shows that annual rate of reduction of IMR is much higher in the post NRHM period. It was near 2 percent in $2000-05$ and its previous years, but after implementation NRHM it has been accelerated to 4 percent in 2005-10 and nearly 6 percent in 2011 (Figure 2).

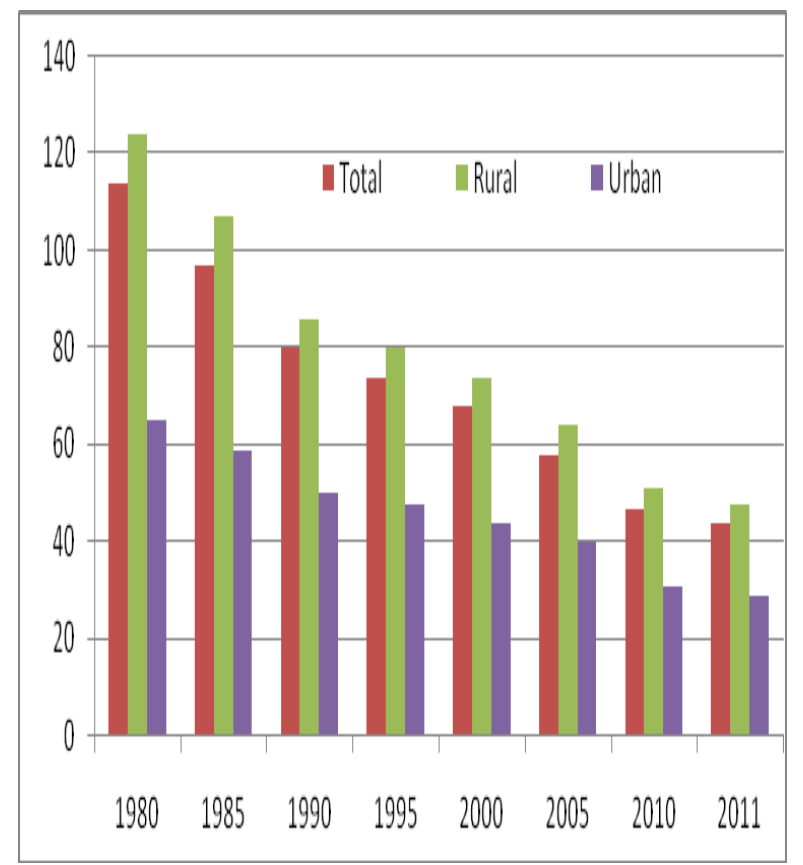

Figure 2. Trends of Infant Mortality Rate in India, 1980-2011. (Source: Sample Registration System, Registrar General of India)

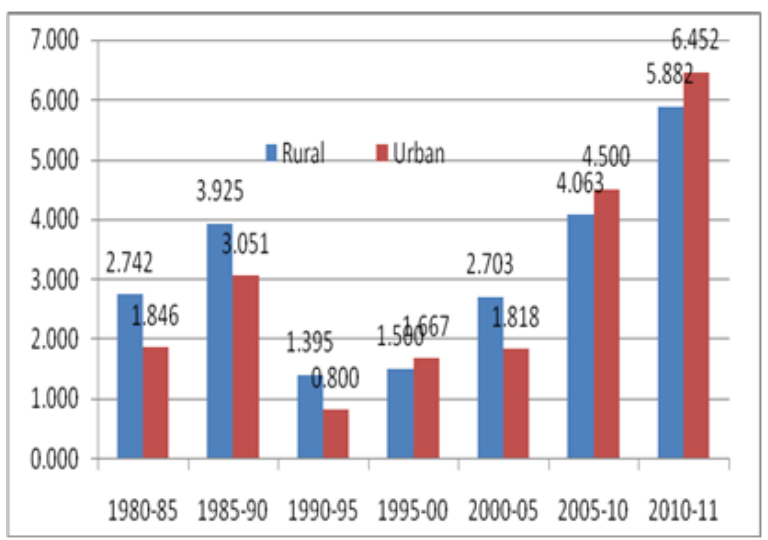

Figure 3. Annual Rate of Reduction in IMR in rural and urban India. (Source: Author's Calculation)

Table 1. Reduction in Infant Mortality Rate in India, 1980-2011

\begin{tabular}{|c|c|c|c|c|}
\hline S.N. & Year & Total & Rural & Urban \\
\hline 1 & 1980 & 114 & 124 & 65 \\
\hline 2 & 1985 & 97 & 107 & 59 \\
\hline 3 & 1990 & 80 & 86 & 50 \\
\hline 4 & 1995 & 74 & 80 & 48 \\
\hline 5 & 2000 & 68 & 74 & 44 \\
\hline 6 & 2005 & 58 & 64 & 40 \\
\hline 7 & 2010 & 47 & 51 & 31 \\
\hline 8 & 2011 & 44 & 48 & 29 \\
\hline
\end{tabular}

Source: SRS, Registrar General of India
Table 2. Annual Rate of Reduction in IMR, 1980-2011

\begin{tabular}{|l|l|l|l|}
\hline S.N. & Year & Rural & Urban \\
\hline 1 & $1980-85$ & 2.742 & 1.846 \\
\hline 2 & $1985-90$ & 3.925 & 3.051 \\
\hline 3 & $1990-95$ & 1.395 & 0.800 \\
\hline 4 & $1995-00$ & 1.500 & 1.667 \\
\hline 5 & $2000-05$ & 2.703 & 1.818 \\
\hline 6 & $2005-10$ & 4.063 & 4.500 \\
\hline 7 & $2010-11$ & 5.882 & 6.452 \\
\hline
\end{tabular}

Source: Author's Calculatio

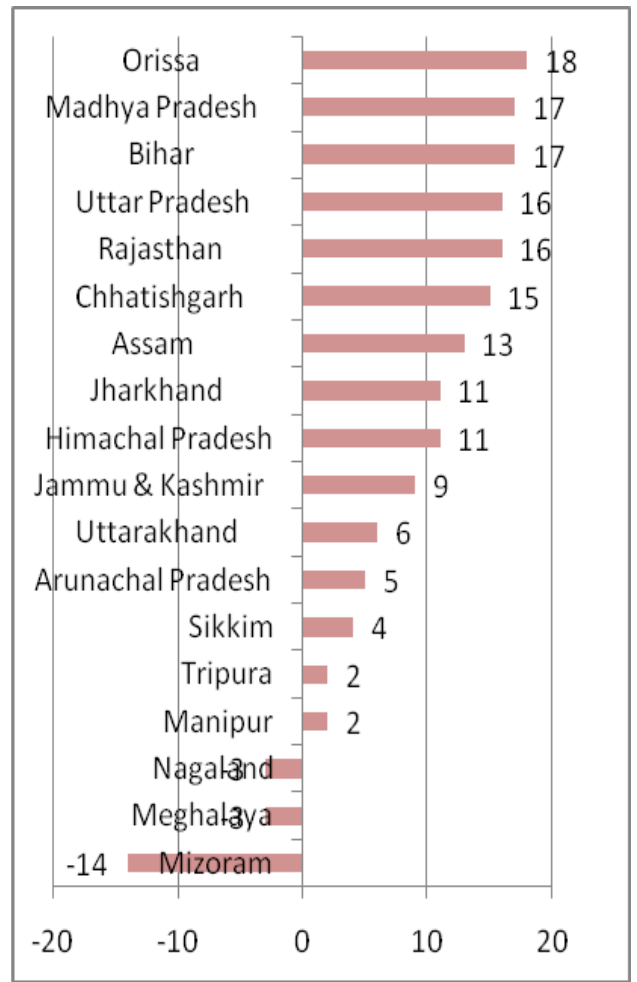

Figure 4. State Wise decline in infant mortality in High Focus states during 2005-11

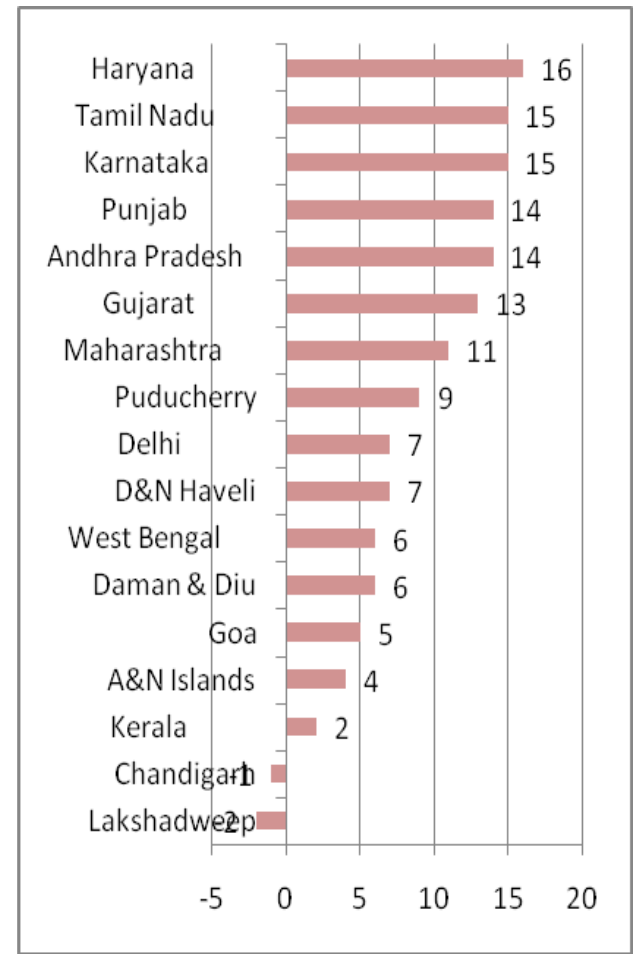

Figure 5. Decline in IMR in India’s non high focus states during 2005-11 


\subsection{Declines in IMR}

As far as the performance of individual states goes in terms of reducing their IMRs, Figure 4 shows, 3 states (Nagaland, Meghalaya and Mizoram) already included in high focus states have noted an increase in IMR. Orissa followed by Madhya Pradesh, Bihar, Uttar Pradesh and Rajasthan have registered a higher reduction in IMRs, while states like Tripura, and Sikkim have witnessed lower declining rate of IMR then national average in this period.

Among non focus seventeen states, the highest decline in IMR have regisered by Haryana followed by Tamil Nadu and Karnataka, while Kerala recorded two points decline during 2005-12. Two states and UTs namely Chandigarh and Lakshadweep have been noticed an increase of one and two points respectively in IMR during the same period.

Table 3. State wise trend of infant mortality rate during 2005-2011

\begin{tabular}{|c|c|c|c|c|c|c|c|c|}
\hline S.N. & States & 2005 & 2006 & 2007 & 2008 & 2009 & 2010 & 2011 \\
\hline 1 & A\&N Islands & 27 & 31 & 34 & 31 & 27 & 25 & 23 \\
\hline 2 & Andhra Pradesh & 57 & 56 & 54 & 52 & 49 & 46 & 43 \\
\hline 3 & Arunachal Pradesh & 37 & 40 & 37 & 32 & 32 & 31 & 32 \\
\hline 4 & Assam & 68 & 67 & 66 & 64 & 61 & 58 & 55 \\
\hline 5 & Bihar & 61 & 60 & 58 & 56 & 52 & 48 & 44 \\
\hline 6 & Chandigarh & 19 & 23 & 27 & 28 & 25 & 22 & 20 \\
\hline 7 & Chhattisgarh & 63 & 61 & 59 & 57 & 54 & 51 & 48 \\
\hline 8 & D\&N Haveli & 42 & 35 & 34 & 28 & 37 & 38 & 35 \\
\hline 9 & Daman \& Diu & 28 & 28 & 27 & 31 & 24 & 23 & 22 \\
\hline 10 & Delhi & 35 & 37 & 36 & 35 & 33 & 30 & 28 \\
\hline 11 & Goa & 16 & 15 & 13 & 10 & 11 & 10 & 11 \\
\hline 12 & Gujarat & 54 & 53 & 52 & 50 & 48 & 44 & 41 \\
\hline 13 & Haryana & 60 & 57 & 55 & 54 & 51 & 48 & 44 \\
\hline 14 & Himachal Pradesh & 49 & 50 & 47 & 44 & 45 & 40 & 38 \\
\hline 15 & Jammu \& Kashmir & 50 & 52 & 51 & 49 & 45 & 43 & 41 \\
\hline 16 & Jharkhand & 50 & 49 & 48 & 46 & 44 & 42 & 39 \\
\hline 17 & Karnataka & 50 & 48 & 47 & 45 & 41 & 38 & 35 \\
\hline 18 & Kerala & 14 & 15 & 13 & 12 & 12 & 13 & 12 \\
\hline 19 & Lakshadweep & 22 & 25 & 24 & 31 & 25 & 25 & 24 \\
\hline 20 & Madhya Pradesh & 76 & 74 & 72 & 70 & 67 & 62 & 59 \\
\hline 21 & Maharashtra & 36 & 35 & 34 & 33 & 31 & 28 & 25 \\
\hline 22 & Manipur & 13 & 11 & 12 & 14 & 16 & 14 & 11 \\
\hline 23 & Meghalaya & 49 & 53 & 56 & 58 & 59 & 55 & 52 \\
\hline 24 & Mizoram & 20 & 25 & 23 & 37 & 36 & 37 & 34 \\
\hline 25 & Nagaland & 18 & 20 & 21 & 26 & 26 & 23 & 21 \\
\hline 26 & Orissa & 75 & 73 & 71 & 69 & 65 & 61 & 57 \\
\hline 27 & Puducherry & 28 & 28 & 25 & 25 & 22 & 22 & 19 \\
\hline 28 & Punjab & 44 & 44 & 43 & 41 & 38 & 34 & 30 \\
\hline 29 & Rajasthan & 68 & 67 & 65 & 63 & 59 & 55 & 52 \\
\hline 30 & Sikkim & 30 & 33 & 34 & 33 & 34 & 30 & 26 \\
\hline 31 & Tamil Nadu & 37 & 37 & 35 & 31 & 28 & 24 & 22 \\
\hline 32 & Tripura & 31 & 36 & 39 & 34 & 31 & 27 & 29 \\
\hline 33 & Uttar Pradesh & 73 & 71 & 69 & 67 & 63 & 61 & 57 \\
\hline 34 & Uttarakhand & 42 & 43 & 48 & 44 & 41 & 38 & 36 \\
\hline \multirow[t]{2}{*}{35} & West Bengal & 38 & 38 & 37 & 35 & 33 & 31 & 32 \\
\hline & INDIA & 58 & 57 & 55 & 53 & 50 & 47 & 44 \\
\hline
\end{tabular}

Data Source: Sample Registration System, Registrar General, India.

\subsection{Progress Made in Infrastructural Facilities during 2005-12}

Table 5 gives an account of the state wise status of infrastructure between 2005 and 2012. The progress of each state in Sub Centers, PHCs and CHCs can be seen from the table. Nine states and UTs have registered a decline in opening new sub centers, while eight states have recorded no change. There are eighteen States and UTs which have noticed an increase in the number of sub centers. It can be seen from Figure 6 that highest progress has been achieved by Chhattisgarh followed by followed by Rajasthan, Orissa and Karnataka. There were 3818 sub centers in 2005 which has been increased to 5111 during 2005-12 in Chhattisgarh and in Rajasthan new 975 sub centers were made available in this period. 
Table 4. Residence wise decline in infant mortality rate between 2005 and 2011

\begin{tabular}{|c|c|c|c|c|c|c|c|c|c|c|}
\hline \multirow[b]{2}{*}{ S.N. } & \multirow[b]{2}{*}{ State } & \multicolumn{3}{|c|}{2011} & \multicolumn{3}{|c|}{2005} & \multicolumn{3}{|c|}{ Decline } \\
\hline & & Total & Rural & Urban & Total & Rural & Urban & Total & Rural & Urban \\
\hline 1 & A\&N Islands & 23 & 28 & 14 & 27 & 30 & 18 & 4 & 2 & 4 \\
\hline 2 & Andhra Pradesh & 43 & 47 & 31 & 57 & 63 & 39 & 14 & 16 & 8 \\
\hline 3 & Arunachal Pradesh & 32 & 36 & 10 & 37 & 39 & 17 & 5 & 3 & 7 \\
\hline 4 & Assam & 55 & 58 & 34 & 68 & 71 & 39 & 13 & 13 & 5 \\
\hline 5 & Bihar & 44 & 45 & 34 & 61 & 62 & 47 & 17 & 17 & 13 \\
\hline 6 & Chandigarh & 20 & 19 & 20 & 19 & 25 & 18 & -1 & 6 & -2 \\
\hline 7 & Chhattisgarh & 48 & 49 & 41 & 63 & 65 & 52 & 15 & 16 & 11 \\
\hline 8 & D\&N Haveli & 35 & 39 & 22 & 42 & 45 & 29 & 7 & 6 & 7 \\
\hline 9 & Daman \& Diu & 22 & 18 & 29 & 28 & 32 & 21 & 6 & 14 & -8 \\
\hline 10 & Delhi & 28 & 36 & 26 & 35 & 44 & 33 & 7 & 8 & 7 \\
\hline 11 & Goa & 11 & 6 & 13 & 16 & 16 & 15 & 5 & 10 & 2 \\
\hline 12 & Gujarat & 41 & 48 & 27 & 54 & 63 & 37 & 13 & 15 & 10 \\
\hline 13 & Haryana & 44 & 48 & 35 & 60 & 64 & 45 & 16 & 16 & 10 \\
\hline 14 & Himachal Pradesh & 38 & 38 & 28 & 49 & 50 & 20 & 11 & 12 & -8 \\
\hline 15 & Jammu \& Kashmir & 41 & 43 & 28 & 50 & 53 & 39 & 9 & 10 & 11 \\
\hline 16 & Jharkhand & 39 & 41 & 28 & 50 & 53 & 33 & 11 & 12 & 5 \\
\hline 17 & Karnataka & 35 & 39 & 26 & 50 & 54 & 39 & 15 & 15 & 13 \\
\hline 18 & Kerala & 12 & 13 & 9 & 14 & 15 & 12 & 2 & 2 & 3 \\
\hline 19 & Lakshadweep & 24 & 21 & 27 & 22 & 17 & 27 & -2 & -4 & 0 \\
\hline 20 & Madhya Pradesh & 59 & 63 & 39 & 76 & 80 & 54 & 17 & 17 & 15 \\
\hline 21 & Maharashtra & 25 & 30 & 17 & 36 & 41 & 27 & 11 & 11 & 10 \\
\hline 22 & Manipur & 11 & 11 & 12 & 13 & 12 & 14 & 2 & 1 & 2 \\
\hline 23 & Meghalaya & 52 & 54 & 38 & 49 & 50 & 42 & -3 & -4 & 4 \\
\hline 24 & Mizoram & 34 & 43 & 19 & 20 & 26 & 10 & -14 & -17 & -9 \\
\hline 25 & Nagaland & 21 & 21 & 20 & 18 & 17 & 22 & -3 & -4 & 2 \\
\hline 26 & Orissa & 57 & 58 & 40 & 75 & 78 & 55 & 18 & 20 & 15 \\
\hline 27 & Puducherry & 19 & 21 & 18 & 28 & 38 & 22 & 9 & 17 & 4 \\
\hline 28 & Punjab & 30 & 33 & 25 & 44 & 49 & 37 & 14 & 16 & 12 \\
\hline 29 & Rajasthan & 52 & 57 & 32 & 68 & 75 & 43 & 16 & 18 & 11 \\
\hline 30 & Sikkim & 26 & 28 & 17 & 30 & 31 & 15 & 4 & 3 & -2 \\
\hline 31 & Tamil Nadu & 22 & 24 & 19 & 37 & 39 & 34 & 15 & 15 & 15 \\
\hline 32 & Tripura & 29 & 31 & 19 & 31 & 31 & 29 & 2 & 0 & 10 \\
\hline 33 & Uttar Pradesh & 57 & 60 & 41 & 73 & 77 & 54 & 16 & 17 & 13 \\
\hline 34 & Uttarakhand & 36 & 39 & 23 & 42 & 56 & 19 & 6 & 17 & -4 \\
\hline \multirow[t]{2}{*}{35} & West Bengal & 32 & 33 & 26 & 38 & 40 & 31 & 6 & 7 & 5 \\
\hline & India & 44 & 48 & 29 & 58 & 64 & 40 & 14 & 16 & 11 \\
\hline
\end{tabular}

Data Source: Sample Registration System, Registrar General, India.

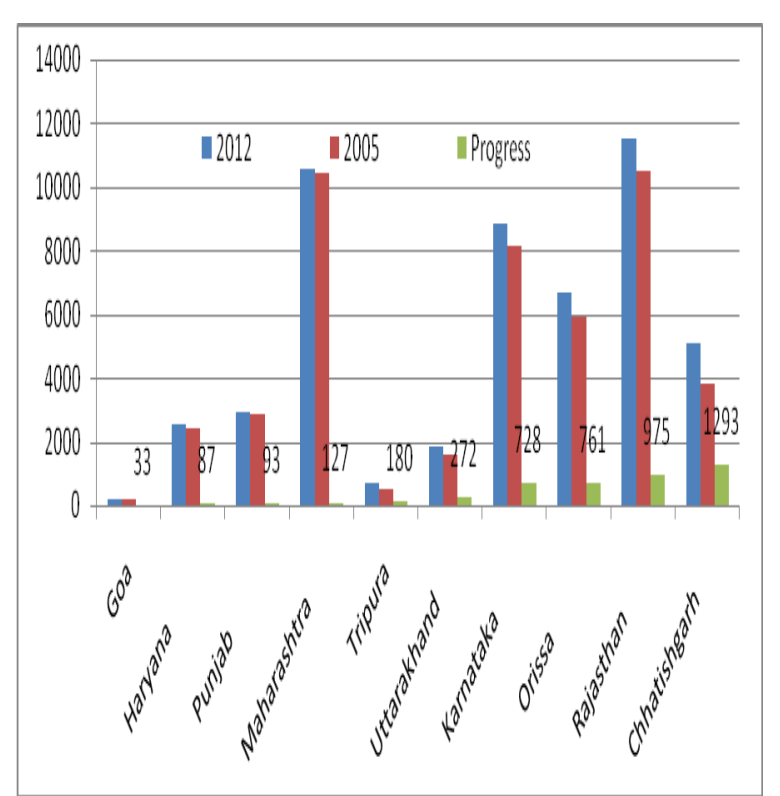

Figure 6. Progress made in Sub-Centers during 2005-12. (Data Source: Rural Health Statistics in India, 2012)

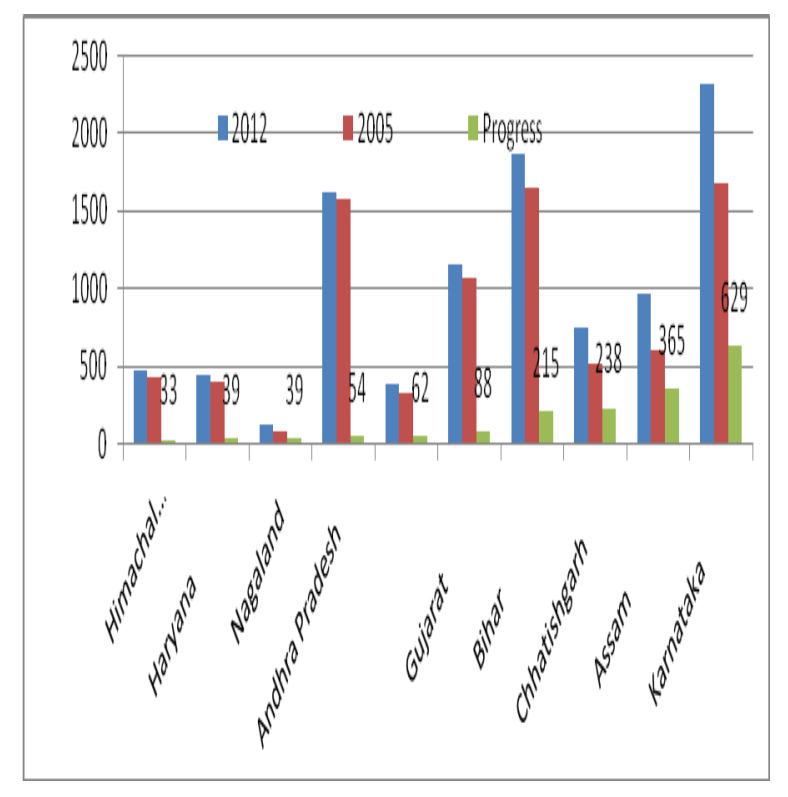

Figure 7. Progress made in PHCs during 2005-12. (Data Source: Rural Health Statistics in India, 2012) 
Table 5. State wise status of health infrastructure facilities in India, 2005-12

\begin{tabular}{|c|c|c|c|c|c|c|c|c|c|c|}
\hline & & \multicolumn{3}{|c|}{2012} & \multicolumn{3}{|c|}{2005} & \multicolumn{3}{|c|}{ Progress } \\
\hline S.N. & States & Sub centre & PHCs & CHCs & Sub centre & PHCs & CHCs & Sub centre & PHCs & CHCs \\
\hline 1 & A\&N Islands & 119 & 22 & 4 & 107 & 20 & 4 & 12 & 2 & 0 \\
\hline 2 & Andhra Pradesh & 12522 & 1624 & 281 & 12522 & 1570 & 164 & 0 & 54 & 117 \\
\hline 3 & Arunachal Pradesh & 286 & 97 & 48 & 379 & 85 & 31 & -93 & 12 & 17 \\
\hline 4 & Assam & 4604 & 975 & 109 & 5109 & 610 & 100 & -505 & 365 & 9 \\
\hline 5 & Bihar & 9696 & 1863 & 70 & 10337 & 1648 & 101 & -641 & 215 & -31 \\
\hline 6 & Chandigarh & 16 & 0 & 2 & 13 & 0 & 1 & 3 & 0 & 1 \\
\hline 7 & Chhattisgarh & 5111 & 755 & 149 & 3818 & 517 & 116 & 1293 & 238 & 33 \\
\hline 8 & D\&N Haveli & 50 & 6 & 1 & 38 & 6 & 1 & 12 & 0 & 0 \\
\hline 9 & Daman \& Diu & 26 & 3 & 2 & 21 & 3 & 1 & 5 & 0 & 1 \\
\hline 10 & Delhi & 41 & 5 & 0 & 41 & 8 & 0 & 0 & -3 & 0 \\
\hline 11 & Goa & 205 & 19 & 5 & 172 & 19 & 5 & 33 & 0 & 0 \\
\hline 12 & Gujarat & 7274 & 1158 & 308 & 7274 & 1070 & 272 & 0 & 88 & 36 \\
\hline 13 & Haryana & 2520 & 447 & 109 & 2433 & 408 & 72 & 87 & 39 & 37 \\
\hline 14 & Himachal Pradesh & 2065 & 472 & 76 & 2068 & 439 & 66 & -3 & 33 & 10 \\
\hline 15 & Jammu \& Kashmir & 1907 & 396 & 84 & 1879 & 334 & 70 & 28 & 62 & 14 \\
\hline 16 & Jharkhand & 3958 & 330 & 188 & 4462 & 561 & 47 & -504 & -231 & 141 \\
\hline 17 & Karnataka & 8871 & 2310 & 180 & 8143 & 1681 & 254 & 728 & 629 & -74 \\
\hline 18 & Kerala & 4575 & 809 & 217 & 5094 & 911 & 106 & -519 & -102 & 111 \\
\hline 19 & Lakshadweep & 14 & 4 & 3 & 14 & 4 & 3 & 0 & 0 & 0 \\
\hline 20 & Madhya Pradesh & 8869 & 1156 & 333 & 8874 & 1192 & 229 & -5 & -36 & 104 \\
\hline 21 & Maharashtra & 10580 & 1811 & 363 & 10453 & 1780 & 382 & 127 & 31 & -19 \\
\hline 22 & Manipur & 420 & 80 & 16 & 420 & 72 & 16 & 0 & 8 & 0 \\
\hline 23 & Meghalaya & 397 & 109 & 29 & 401 & 101 & 24 & -4 & 8 & 5 \\
\hline 24 & Mizoram & 370 & 57 & 9 & 366 & 57 & 9 & 4 & 0 & 0 \\
\hline 25 & Nagaland & 396 & 126 & 21 & 394 & 87 & 21 & 2 & 39 & 0 \\
\hline 26 & Orissa & 6688 & 1226 & 377 & 5927 & 1282 & 231 & 761 & -56 & 146 \\
\hline 27 & Puducherry & 51 & 24 & 4 & 76 & 39 & 4 & -25 & -15 & 0 \\
\hline 28 & Punjab & 2951 & 449 & 132 & 2858 & 484 & 116 & 93 & -35 & 16 \\
\hline 29 & Rajasthan & 11487 & 1528 & 382 & 10512 & 1713 & 326 & 975 & -185 & 56 \\
\hline 30 & Sikkim & 147 & 24 & 2 & 147 & 24 & 4 & 0 & 0 & -2 \\
\hline 31 & Tamil Nadu & 8706 & 1227 & 385 & 8682 & 1380 & 35 & 24 & -153 & 350 \\
\hline 32 & Tripura & 719 & 79 & 12 & 539 & 73 & 10 & 180 & 6 & 2 \\
\hline 33 & Uttar Pradesh & 20521 & 3692 & 515 & 20521 & 3660 & 386 & 0 & 32 & 129 \\
\hline 34 & Uttarakhand & 1848 & 257 & 59 & 1576 & 225 & 44 & 272 & 32 & 15 \\
\hline 35 & West Bengal & 10356 & 909 & 348 & 10356 & 1173 & 95 & 0 & -264 & 253 \\
\hline & INDIA & 148366 & 24049 & 4833 & 146026 & 23236 & 3346 & 2340 & 813 & 1487 \\
\hline
\end{tabular}

Data Source: Rural Health Statistics in India, 2012. Ministry of Health and Family Welfare, Government of India, 30 April, 2013.

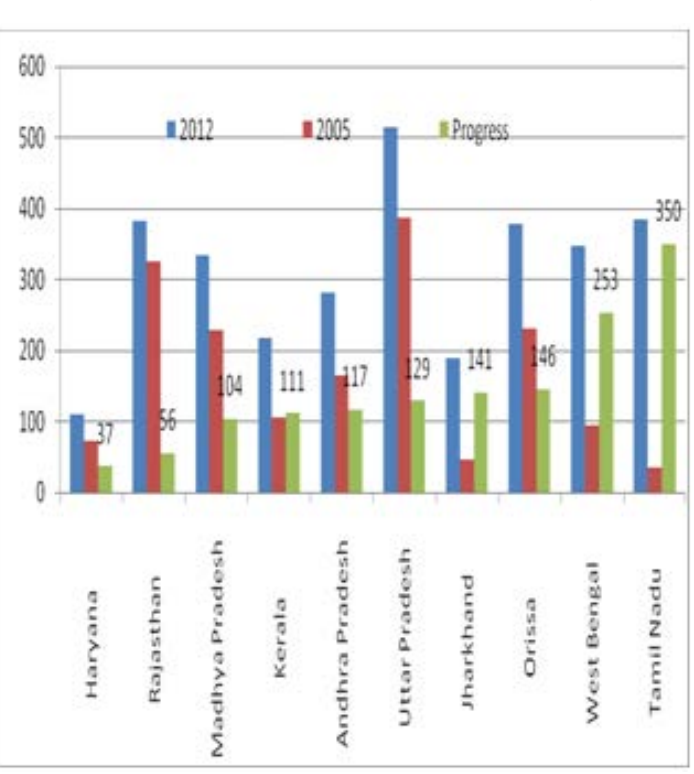

Figure 8. Progress made in CHCs during 2005-12. (Data Source: Rural Health Statistics in India, 2012)
The PHC is the first point of contact with a qualified doctor for people in rural areas. Uttar Pradesh has the largest number of functioning PHCs followed by Bihar, Maharashtra and Andhra Pradesh. Seven States and UTs namely Chandigarh, D\& N Haveli, Daman \& Diu, Goa, Lakshadweep, Mizoram and Sikkim have recorded no change in the number of functioning PHCs in this period. Karnataka has made the largest progress in the number of PHCs followed by Assam, Chhattisgarh and Bihar during 2005-2012 (Figure 7).

For the CHCs the nine states and UTs recorded no change, while four states and UTs have noticed declines in the number of functioning CHCs during 2005-12. Tamil Nadu registered highest progress of 350 CHCs in this period followed by West Bengal, Orissa and Jharkhand Figure 8.

\subsection{Progress Made in Manpower facilities during 2005-12}

Along with physical infrastructure, the availability of human resources is a significant determinant of the quality 
of health care at PHCs and CHCs. In this section, we have number of doctors and a number of specialists. included a number of ANM/ female health workers,

Table 6. State wise status of man power facilities in India, 2005-12.

\begin{tabular}{|c|c|c|c|c|c|c|c|c|c|}
\hline \multirow[b]{2}{*}{ State \& UTs } & \multicolumn{3}{|c|}{2012} & \multicolumn{3}{|c|}{2005} & \multicolumn{3}{|c|}{ Progress } \\
\hline & ANM & Doctor & Specialists & ANM & Doctor & Specialists & ANM & Doctor & Specialists \\
\hline A\&N Islands & 193 & 33 & 0 & 127 & 36 & 0 & 66 & -3 & 0 \\
\hline Andhra Pradesh & 21853 & 3448 & 346 & 13740 & 2137 & 224 & 8113 & 1311 & 122 \\
\hline Arunachal Pradesh & 395 & 92 & 1 & 454 & 78 & 0 & -59 & 14 & 1 \\
\hline Assam & 8723 & 1478 & 122 & 5719 & 610 & NA & 3004 & 868 & NA \\
\hline Bihar & 16943 & 3532 & 151 & 11985 & 1648 & NA & 4958 & 1884 & NA \\
\hline Chandigarh & 29 & 0 & 11 & 13 & 0 & NA & 16 & 0 & NA \\
\hline Chhattisgarh & 5468 & 435 & 71 & 3667 & 628 & 18 & 1801 & -193 & 53 \\
\hline D\&N Haveli & 82 & 6 & 0 & 38 & 6 & NA & 44 & 0 & NA \\
\hline Daman \& Diu & 39 & 5 & 2 & 24 & 5 & NA & 15 & 0 & NA \\
\hline Delhi & 41 & 22 & 0 & 51 & 23 & NA & -10 & -1 & NA \\
\hline Goa & 240 & 41 & 6 & 179 & 53 & 7 & 61 & -12 & -1 \\
\hline Gujarat & 6431 & 778 & 76 & 6508 & 848 & 92 & -77 & -70 & -16 \\
\hline Haryana & 4973 & 342 & 19 & 2818 & 862 & 49 & 2155 & -520 & -30 \\
\hline Himachal Pradesh & 1951 & 436 & 5 & 1790 & 467 & NA & 161 & -31 & NA \\
\hline Jammu \& Kashmir & 3941 & 845 & 173 & 1588 & 643 & 142 & 2353 & 202 & 31 \\
\hline Jharkhand & 6574 & 407 & 86 & 5023 & 561 & NA & 1551 & -154 & NA \\
\hline Karnataka & 11434 & 2089 & 495 & 8544 & 2041 & 691 & 2890 & 48 & -196 \\
\hline Kerala & 4173 & 1152 & 774 & 5565 & 949 & 82 & -1392 & 203 & 692 \\
\hline Lakshadweep & 39 & 9 & 0 & 22 & 4 & 0 & 17 & 5 & 0 \\
\hline Madhya Pradesh & 10204 & 814 & 267 & 9345 & 839 & 49 & 859 & -25 & 218 \\
\hline Maharashtra & 22135 & 2760 & 514 & 10699 & 3158 & 1099 & 11436 & -398 & -585 \\
\hline Manipur & 975 & 170 & 1 & 463 & 67 & 19 & 512 & 103 & -18 \\
\hline Meghalaya & 787 & 104 & 9 & 608 & 123 & 1 & 179 & -19 & 8 \\
\hline Mizoram & 650 & 49 & 0 & 345 & 35 & 0 & 305 & 14 & 0 \\
\hline Nagaland & 867 & 99 & 9 & 342 & 53 & 0 & 525 & 46 & 9 \\
\hline Orissa & 8211 & 1069 & 317 & 6768 & 1353 & NA & 1443 & -284 & NA \\
\hline Puducherry & 231 & 63 & 0 & 115 & 63 & 6 & 116 & 0 & -6 \\
\hline Punjab & 4199 & 457 & 279 & 2602 & 373 & 226 & 1597 & 84 & 53 \\
\hline Rajasthan & 17638 & 1755 & 148 & 11425 & 1506 & 581 & 6213 & 249 & -433 \\
\hline Sikkim & 291 & 32 & 0 & 260 & 48 & 4 & 31 & -16 & -4 \\
\hline Tamil Nadu & 9253 & 2271 & 0 & 10112 & 2257 & 48 & -859 & 14 & -48 \\
\hline Tripura & 1169 & 119 & 0 & 561 & 152 & 2 & 608 & -33 & -2 \\
\hline Uttar Pradesh & 22464 & 2861 & 1740 & 18146 & 3660 & NA & 4318 & -799 & NA \\
\hline Uttarakhand & 2016 & 205 & 51 & 1486 & 182 & 71 & 530 & 23 & -20 \\
\hline West Bengal & 12966 & 1006 & 175 & 9070 & 1319 & 133 & 3896 & -313 & 42 \\
\hline India & 1851144 & 28984 & 5858 & 133194 & 20308 & 3550 & 1717950 & 8676 & 2308 \\
\hline
\end{tabular}

Data Source: Rural Health Statistics in India, 2012. Ministry of Health and Family Welfare, Government of India, 30 April, 2013.

Table 7 a. Coefficients ${ }^{a}$

\begin{tabular}{|c|c|c|c|c|c|c|}
\hline \multicolumn{2}{|c|}{ Model } & \multicolumn{2}{|c|}{$\begin{array}{c}\text { Unstandardized } \\
\text { Coefficients }\end{array}$} & $\begin{array}{c}\text { Standardized } \\
\text { Coefficients }\end{array}$ & \multirow{2}{*}{$\mathrm{t}$} & \multirow{2}{*}{ Sig. } \\
\cline { 2 - 5 } & B & $\begin{array}{c}\text { Std. } \\
\text { Error }\end{array}$ & Beta & & \\
\hline \multirow{2}{*}{1} & \begin{tabular}{c} 
(Constant) \\
\cline { 2 - 6 }
\end{tabular} & 6.173 & 1.343 & & 4.596 & .000 \\
\cline { 2 - 6 } & $\begin{array}{c}\text { Increase in } \\
\text { the number } \\
\text { of ANMs }\end{array}$ & .001 & .000 & .424 & 2.692 & .011 \\
\hline
\end{tabular}

a. Dependent Variable: Decline in Infant Mortality Rate

$\mathrm{R}$ Square $=.18$ Adjusted $\mathrm{R}$ Square $=.155 \mathrm{~F}(1,33)=7.24$ Sig. $=.011$
Table 7 b. Coefficients ${ }^{\mathrm{a}}$

\begin{tabular}{|c|c|c|c|c|c|c|}
\hline \multirow{2}{*}{ Model } & \multicolumn{2}{|c|}{$\begin{array}{c}\text { Unstandardized } \\
\text { Coefficients }\end{array}$} & $\begin{array}{c}\text { Standardized } \\
\text { Coefficients }\end{array}$ & \multirow{2}{*}{$\mathrm{t}$} & \multirow{2}{*}{ Sig. } \\
\cline { 2 - 5 } & $\mathrm{B}$ & $\begin{array}{c}\text { Std. } \\
\text { Error }\end{array}$ & Beta & & \\
\hline \multirow{2}{*}{1} & (Constant) & 7.405 & 1.593 & & 4.649 & .000 \\
\cline { 2 - 6 } & $\begin{array}{c}\text { Increase in the } \\
\text { number of } \\
\text { ANMs }\end{array}$ & .001 & .001 & .353 & 2.165 & .038 \\
\hline
\end{tabular}

a. Dependent Variable: Decline in Infant Mortality Rate (Rural)

$\mathrm{R}$ Square $=.124$ Adjusted R Square $=.098 \mathrm{~F}(1,33)=4.687$ Sig. $=.038$ 
Table 7 c. Coefficients ${ }^{a}$

\begin{tabular}{|c|c|c|c|c|c|c|}
\hline \multicolumn{2}{|c|}{ Model } & \multicolumn{2}{|c|}{$\begin{array}{c}\text { Unstandardized } \\
\text { Coefficients }\end{array}$} & $\begin{array}{c}\text { Standardized } \\
\text { Coefficients }\end{array}$ & \multirow{2}{*}{$\mathrm{t}$} & Sig. \\
\cline { 2 - 5 } & $\mathrm{B}$ & $\begin{array}{c}\text { Std. } \\
\text { Error }\end{array}$ & Beta & & \\
\hline \multirow{3}{*}{1} & (Constant) & 4.221 & 1.257 & & 3.359 & .002 \\
\cline { 2 - 6 } & $\begin{array}{c}\text { Increase in the } \\
\text { number of } \\
\text { ANMs }\end{array}$ & .001 & .000 & .370 & 2.289 & .029 \\
\hline
\end{tabular}

a. Dependent Variable: Decline in Infant Mortality Rate (Urban) $\mathrm{R}$ Square $=.137$ Adjusted $\mathrm{R}$ Square $=.111 \mathrm{~F}(1,33)=5.241$ Sig. $=.029$

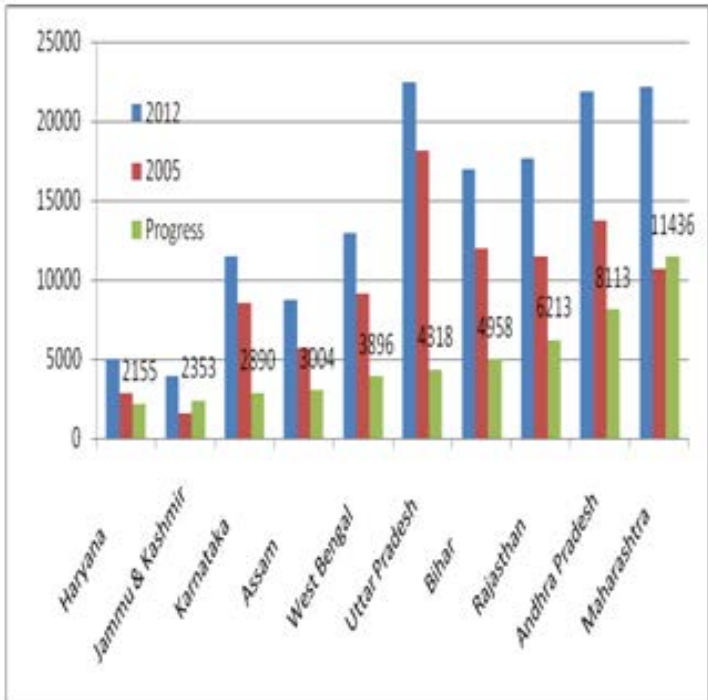

Figure 9. Progress made in manpower (ANM) during 2005-12. (Data Source: Rural Health Statistics in India, 2012)

Between 2005 and 2012, there has been a decline registered in a number of ANMs in five states namely Kerala, Tamil Nadu, Gujarat, Arunachal Pradesh and Delhi, while seven states have recorded an increase of less than hundred. Table 3, shows that nine states and UTs have registered an increase in the number of ANMs between one hundred and one thousand. Only fourteen states have satisfactory progress in this regard. Figure 9 shows Maharashtra has recorded highest progress of 11436 ANMs followed by Andhra Pradesh, Rajasthan and Bihar in giving new appointments to ANMs or female health workers during 2005-12.

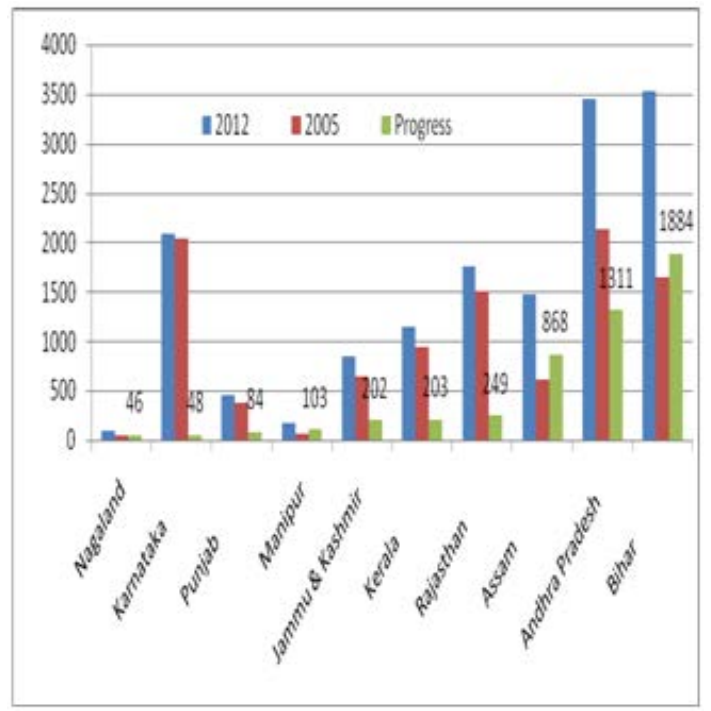

Figure 10. Progress made in manpower (Doctor) during 2005-12. (Data Source: Rural Health Statistics in India, 2012)
Data up to April 2013 reports that, twenty states and UTs have recorded no change in the number of doctors working at PHCs \& CHCs, while five states have made substantial progress of appointing less than twenty five new doctors during 2005 -12. Figure 10 shows that Bihar, Andhra Pradesh, Assam and Rajasthan are among the best performers in this respect during 2005-12.

The availability of specialists (surgeons, pediatricians, physicians and obstetrician and gynecologists), at CHCs is far worse. There are significant improvement in the number of specialists in Andhra Pradesh, Karnataka, Maharashtra and Rajasthan during 2005 -12.

\section{Have Physical Infrastructure and Manpower Facilities Reduced IMR in India?}

In this paper an attempt has made to establish a relationship between declines in infant mortality rate and progress made in health infrastructure (Sub centers, PHCs \& CHCs) and manpower (ANMs \& Doctors) ${ }^{2}$ during 2005-12. Using a decline in infant mortality rate during 2005-12 as dependent variable and progress made in a number of sub centers, number of PHCs, number of CHCs, number of ANMs and the number of doctors during 200512 as independent variables, we ran stepwise regression. Results of stepwise regression analysis show that an increase in female health workers or ANMs have statistically significant at 1 percent level positive association with a decline in infant mortality rate in India as remaining other relevant variables constant. When dataset divided in rural and urban, it has also statistical significant 5\% level positive association between decline in IMR and increase in the number of ANMs.

\section{Conclusion}

Using review of available data sources and published literature, this paper aims to examine the scenario of infant mortality over the last seven years and the impact of NRHM initiatives like health infrastructure and manpower over the same.

To find out the impact of NRHM on Infant mortality rate, we have calculated annual rate of reduction in IMR (Figure 2). It clearly shows that annual rate of reduction of IMR is much higher in the post NRHM period. It was near 2 percent in $2000-05$ and its previous years, but after implementation NRHM it has been accelerated to 4 percent in 2005-10 and nearly 6 percent in 2011. As far as the performance of individual state is concerned, Orissa followed by Madhya Pradesh, Bihar, Uttar Pradesh and Rajasthan have registered a higher reduction in IMRs, while states like Tripura, Manipur and Kerala have witnessed lower declining rate of IMR then national average in this period.

The highest progress in functioning sub centers has been achieved by Chhattisgarh followed by followed by Rajasthan, Orissa and Karnataka, while Uttar Pradesh has the largest number of functioning PHCs followed by Bihar, Maharashtra and Andhra Pradesh. Tamil Nadu registered highest progress of 350 CHCs in this period followed by West Bengal, Orissa and Jharkhand. Maharashtra has 
recorded highest progress of 11436 ANMs followed by Andhra Pradesh, Rajasthan and Bihar in giving new appointments to ANMs or female health workers during 2005-12. Bihar, Andhra Pradesh, Assam and Rajasthan are among the best performers in doctors during 2005-12. Results of stepwise regression analysis show that an increase in female health workers or ANMs have statistically significant at 1 percent level positive association with a decline in infant mortality rate in India as remaining other relevant variables constant.

\section{Notes}

1. This information was given by Minister of State for Health \& Family Welfare Abu Hasem Khan Choudhury in written reply to a question in the Rajya Sabha (Upper House of the Parliament)

2. The number of specialists is not available for many of the states, and that is why, the number of specialists was not used as independent variable in a regression analysis.

\section{References}

[1] Sharma S, Childhood Mortality and Health in India, Institute of Economic Growth, Working paper series No. E /292, 2008.

[2] Nair H \& Panda R, Quality of maternal healthcare in India: Has the National Rural Health Mission made a difference? , Journal of Global Health, Vol. 1, No. 1, 2011, PP79-86.

[3] Sen, A.K., Africa and India: What do we have to learn from each other? Discussion paper no. 19, United Nations University, WIDER, 1987.

[4] Sen, A.K., Mortality as an indicator of economic success and failure, the economic Journal, Vol. 108, No 446, 1998.

[5] Congressional Budget Office., Factors Contributing to the Infant Mortality Rankings of the UnitedStates., February 1992.
[6] MacDorman MF, Mathews TJ., Recent Trends in Infant Mortality in the United States. NCHS data brief, no9. Hyattsville, MD: National Center for HealthStatistics. 2008.

[7] Boone, Peter, "Politics and the Effectiveness of Foreign Aid," European EconomicReview, Vol. 40, Issue 2 (February), pp. 289329, 1996.

[8] Himmelstein, David U., and Woolhandler, Steffie., Cost Without Benefit. New England Journal of Medicine 314: 441-45. 1986.

[9] Shortell, Stephen M., and Hughes, F.X., The Effects of Regulation, Competition, and Ownership on Mortality Rates among Hospital Inpatients. New England Journal of Medicine 318:1100-1107, 1988.

[10] Ohsfeldt, Robert L., If the Business Model of Medicine Is Sick, What's the Diagnosis and What's the Cure? Independent Review 8: 271-283, 2003.

[11] Ahlbrandt, Roger S. Jr., Efficiency in theProvision of Fire Service. Public Choice 16: 1-15, 1973.

[12] Stigler, George J., The Theory of Economic Regulation. Bell Journal of Economics and ManagementSciences 2:137-46, 1971;

[13] Friedman, Milton., How to cure health care. The Public Interest. pp. 3-30, Winter 2001.

[14] Santerre, R.E., Grubauch, S. G., and Stollar, A.J., Government Intervention in Health Care Markets and Health Care Outcomes: Some International Evidence. Cato Journal 11: 1-12, 1991.

[15] Hossain, J. \& Kamal K.M., An Econometric Investigation of Infant Mortality Scenarios in Bangladesh, Journal of Business and Economics, Vol. 5, No. 1\&2, 2010, PP 97-105.

[16] Caldwell, J.C., Education as a factor in mortality decline: an examination of Nigerian data, Population Studies, Vol. 33, No.3, 1979, PP. 395-413.

[17] Roenzwig. M. and K. Wolpin, "Government Interventions and a household behaviour in developing countries: anticipating and unanticipated consequences of social programs" Journal of Development Economics, 10 (1982); 209-225.

[18] Da Vanz, J., ”A household survey of child mortality determinants in Malaysia" Population and Development Review, Supplement to volume 10, 1984, pp 307-323.

[19] Das A, Socioeconomic Development in India: A Regional Analysis, Development and Society, Volume 28/2 Dec, 1999, pp 313-45.

[20] Gujarati, D. N., Basic Econometrics, $4^{\text {th }}$ Edition, McGraw-Hill International Edition, 2003.

[21] Miller, B., female labour participation and female seclusion in rural India: a regional view, economic development and cultural change, Vol. 30, No. 4, 1982. 